\title{
Disrupting Dominant Discourses: A (Re)Introduction to Social Practice Theories of Adult Numeracy
}

Helen M. Oughton

University of Bolton, h.oughton@bolton.ac.uk

Follow this and additional works at: https://digitalcommons.usf.edu/numeracy

Part of the Adult and Continuing Education Commons, and the Science and Mathematics Education Commons

\section{Recommended Citation}

Oughton, Helen M.. "Disrupting Dominant Discourses: A (Re)Introduction to Social Practice Theories of Adult Numeracy." Numeracy 11, Iss. 1 (2018): Article 2. DOI: https://doi.org/10.5038/1936-4660.11.1.2 


\title{
Disrupting Dominant Discourses: A (Re)Introduction to Social Practice Theories of Adult Numeracy
}

\author{
Abstract \\ The role of dominant discourse in constructing a deficit view of adult numeracy is examined, using \\ reports from recent international surveys of adult skills as illustrative examples. Social practice theory is \\ introduced as an alternative perspective for examining the ways adults actually use numeracy in their \\ daily lives and work. This perspective suggests the test items used by large-scale surveys such as PIACC \\ are only proxies for real-life numeracy skills, and that performance in such tests may misrepresent the \\ numeracy skills of adults. Instead, social practice theory suggests that adults may have informal, situated \\ numeracy practices that serve them adequately in their daily lives. However, it also draws attention to the \\ difficulty of transferring mathematics from the classroom to everyday numeracy situations, while it \\ recognizes that adult numeracy learners may be motivated by other goals than functional numeracy, such \\ as personal fulfillment or a gateway qualification. Alternative approaches to classroom teaching for adult \\ students are suggested which acknowledge and draw on adults' rich and varied experiences; the \\ challenges and tensions of such approaches are explored.
}

\section{Keywords}

adult numeracy, discourse analysis, deficit discourses about competencies, PIAAC assessment, social practice theory, functional numeracy, situated numeracy, mathematics education, classroom mathematics

\section{Creative Commons License}

\section{cc) (7) (8)}

This work is licensed under a Creative Commons Attribution-Noncommercial 4.0 License

\section{Cover Page Footnote}

Helen Oughton's background is in adult education, specialising in adult numeracy and literacy. Her research interests focus on ideology, discourse and power in mathematics and numeracy education. She is currently a researcher and Ph.D. supervisor at University of Bolton, England. 


\section{Introduction}

Large-scale international research suggests that nearly a third of all adults in the United States have "weak" numeracy skills and quantitative literacy (QL). ${ }^{1}$ Low attainment in numeracy amongst adults is reported to be associated with unemployment, the need for social assistance, and an overall adverse effect on the national economy (OECD 2013a, 2013b; NCES 2016).

Such claims are probably familiar to readers of this journal. However, when they are reported in the mainstream media, the result can be a "moral panic" (Coben 2001). For example, people perceived as having low numeracy skills are often seen by policy-makers - and by the general public - as being in deficit. Thus they are to blame for their own problems, and they are an economic burden on the society in which they live (Coben 2001; Yasukawa and Black 2016).

My aim in this article is to introduce readers who have not encountered it before to the social practice model of numeracy - a perspective that can be used to challenge and disrupt the deficit discourses dominating policy documentation and reports.

While this perspective is not new, it is perhaps more widely accepted in some research communities (particularly those in the UK) than in others. My aim here is to introduce the ideas to a new readership, preparing the way for future papers within this paradigm in this journal (see also Karaali et al. 2016).

I begin with a short introduction to the ways in which discourse can influence how individuals perceive themselves and others within the social world, and I demonstrate how mainstream documents and reports often use a "deficit discourse" that promotes and reinforces a negative view of adults' numeracy ability.

I then trace the development of alternative ways of thinking about how adults use numeracy in their everyday lives and work, and in particular, social practice theory (Baker 1998; Street, Baker and Tomlin 2005). Using social practice theory as an alternative lens, I revisit dominant discourses to illustrate the different interpretations this more critical lens can offer.

I conclude with some suggestions for how these perspectives can be applied to an adult ${ }^{2}$ education context (for example, adults studying mathematics in community colleges or for the GED mathematics exam), to provide learning

\footnotetext{
${ }^{1}$ I shall use "numeracy" because it is more widely used than QL in an international adult education context. See Karaali et al. (2016) for a discussion of these terms.

2 The term "adult" in this article refers to those beyond the age of compulsory schooling, who are therefore using numeracy to solve problems generated by their own goals and purposes, whether these problems occur in the workplace, further or higher education settings, or everyday life.
} 
opportunities which are more relevant for adult students and which acknowledge the rich and varied life experiences that adults bring to their learning.

\section{Dominant Discourses in Adult Numeracy}

The role that discourse analysis can play in numeracy (or QL) has been introduced recently in this journal by Tunstall (2016). Here I take the discussion further, to illustrate how particular types of discourse dominate perceptions of adult numeracy, and how these discourses can influence assumptions and beliefs of teachers, students and policy makers.

What is "discourse," and how does it differ from simply "language"? One definition is language-in-use that is used to communicate and is felt to be coherent (Crystal 1992). Discourse may be spoken or written, but it can also include other forms of semiosis (meaning-making), such as intonation, gestures, images, symbols, and even the layout used to present written text. However, many scholars take the matter deeper; they consider discourse as a passage of language or text in terms of the social action it performs and the context in which it is found. Discourse therefore (Cook 1989):

- is produced and consumed by social actors,

- is shaped by social structures,

- has social implications, and

- is socially valued and regulated.

A further nuance, and the way the word "discourse" will be used throughout the remainder of this article, is to describe it as ways of writing and speaking which (Gee 1996; Papen 2005; Wodak and Meyer 2015):

- $\quad$ are inherently ideological,

- invoke a set of powerful values and viewpoints, and

- resist criticism by marginalizing alternative values and viewpoints.

Writing of the discourse of policy texts, Fairclough (1989) defines ideology as the power to project one's practices as universal and common-sense. Ideology is most effective when its workings are least visible, and, through naturalization, types of discourse appear to lose their ideological character. Luke $(1995,8)$ explains how discourse can shape "grids and hierarchies for the institutional categorisation and treatment of people." Discourse constructs assumptions about the natural and social world by which members of communities define themselves and others. According to Luke, when people internalize discourses, they become complicit in their own regulation. Dominant discourses can thus be very powerful 
in influencing how individuals perceive the social world, the apparent "truths" (or ideologies) which govern it, and their own position within it.

\section{Economistic Discourses and Deficit Discourses}

Readers of this journal may already be familiar with findings about the extent of, and the social and economic outcomes of, low numeracy skills in the adult population in the United States and other developed countries. For example, findings from the 2012-2016 round of the PIAAC ${ }^{3}$ international survey of adult skills included the following (OECD 2013b; AIR 2014):

- Nearly one in three adults in the United States was assessed as having "weak" numeracy skills (i.e., a higher proportion of low-skilled adults than most participating countries).

- In the United States, the odds of having low levels of health are four times as high for low-skilled adults. Three out of ten people with low skills report having only "fair" to "poor" health.

- Children of parents with low numeracy skills are more likely to have low skills themselves (an association stronger in the United States than in most other participating countries).

- Only two-thirds of adults assessed as having low skills in the United States are employed, and mostly in semi-skilled blue- and white-collar occupations with low incomes.

- Adults with lower skill levels are less likely to feel trust in others, to believe that people like themselves have a say in what the government does, and to engage in the volunteer activities that sustain a rich civil society.

Such findings are, of course, highly valuable in drawing the attention of policy makers to the importance of adult numeracy, and in making the case for government funding of adult numeracy education.

However, the way in which such findings are reported can reflect dominant ideologies in their discourse, leading to a "deficit" view, in which people assessed as having low numeracy are represented as being "to blame" for their own difficulties, or "a burden" on the state (Papen 2005).

\footnotetext{
${ }^{3}$ The Program for the International Assessment of Adult Competencies (PIAAC), led by the Organization for Economic Cooperation and Development (OECD). The survey uses computerbased test items to assess the numeracy, literacy and technology skills of 16-65 year olds. A background questionnaire is used to collect other personal information, such as educational attainment and employment status, allowing relationships between these variables and assessed skills to be investigated. These findings are used to make recommendations for education policy in the participating countries.
} 
Yasukawa and Black (2016) draw attention to the rise in the "economistic" or human capital view of adult skills, in which learning is seen as the acquisition of skills by the workforce so that their country can compete in the world economy.

Literacy and numeracy are now perceived primarily in terms of human capital, variously expressed as 'core', 'foundation', 'essential' or 'functional' skills that enable individuals, enterprises and nations to become more productive and competitive in the globalised economy. Such discourses often ignore the diverse meanings held about literacy and numeracy by the workers themselves and other key actors in the field, including learners, teachers and researchers (Yasukawa and Black 2016, ix)

For example, in Skilled for Life?, a document reporting headline findings from the PIAAC survey, the OECD claim that:

Without the right skills, people are kept at the margins of society, technological progress does not translate into economic growth, and enterprises and countries can't compete in today's globally connected and increasingly complex world (OECD 2013a).

Papen (2005) points out that a deficit view can be reinforced by language choices, such as the use of metaphor when presenting innumeracy as an "epidemic." For example, Skilled for Life? describes large numbers of adults being unable to cope or function; "struggling," "unaware" and "confused" (OECD 2013a). The choice of pronouns can also be powerful in positioning certain members of the population as "other." The OECD documentation uses the inclusive "we" to address the reader:

The way we live and work has changed profoundly - and so has the set of skills we need to participate fully in and benefit from our hyper-connected societies and increasingly knowledge-based economies ... [the PIAAC results] will show us where we are, where we need to be, and how to get there if we want to be fully engaged citizens in a global economy. (OECD 2013a, 3; my emphasis)

However, the report tends to use phrases such as "they" or "these adults" when describing adults assessed as having low skills; for example:

Large proportions of adults struggle with the most basic skills .... They can, at best, perform one-step or simple mathematical processes (OECD 2013a, 8; my emphasis).

While I have focussed here on recent PIAAC documentation, other analyses show similar policy discourses in many developed countries over the last decade (e.g., Papen 2005; Oughton 2007; Evans 2013; Hamilton 2016). Such discourses promote a human capital view of education; they position adults assessed as having low skills as "other" from the reader and society - out-of-touch, disengaged, and not contributing sufficiently to the economy. As Luke (1995) suggests, such discourse can create and maintain strongly held beliefs about the social world by which individuals define themselves and others. 


\section{Social Practice Theory: An Alternative Lens}

In contrast to the foregoing views, there are alternative ways to look at the numeracy skills of adults. The remainder of this article presents the social practice model of numeracy. This model offers a broader understanding of the way in which adults use mathematics in their lives, and of the role of adult education.

\section{Early research}

Lerman (2000, 36) describes the "social turn" in mathematics and numeracy research, beginning in the 1980s, toward accounts which brought together "agency, individual trajectories, and the cultural, historical, and social origins of the way people think, behave, reason, and understand the world."

Rather than regarding numeracy as a set of abstract mathematical skills that can be learned in the classroom and subsequently applied without problems to other contexts, researchers turned to methodologies that allowed them to observe in more detail how adults actually use numeracy in their everyday lives. Early research within this ethnographic perspective included studies of children living by selling watermelons and candy in Brazil (Carraher, Carraher and Schliemann 1985; Saxe 1988) and adults working as market traders, fishermen, builders, carpenters and farmers in Brazil (Nunes, Schliemann and Carraher 1993). These studies found, for example, that participants used their own "street methods" of mental calculation to work out the correct change to give customers.

Similarly, Lave (1988) studied adults' grocery shopping and weight-watching in the United States. Again she found that adults used their own situated numeracy practices rather than those typically taught in the classroom. For example, adult dieters often did not weigh foods to calculate calories; instead, they used known kitchen containers to estimate quantities.

The common theme emerging from these and similar studies was that the situated numeracy practices undertaken by the participants were fundamentally different from mathematics as it is usually practiced in the classroom. The reallife problems to be solved were generated by the participants themselves, and the problems were structured in terms of goals to be achieved, rather than mathematics, with social relationships being central to many of the practices. Participants maintained control of the problem-solving process. They could decide how to solve the problems, and they could determine whether a precise or approximate answer was required. Participants who might struggle with written problems in the classroom were found to perform competently within these meaningful contexts. Lave (1988) found, for example, that adults were 93\% correct in their "best-buy" problem-solving in supermarket situations, compared with only 44\% in pen-and-paper testing (Capon and Kuhn 1979). 
In response to such studies, an alternative model of adult numeracy started to be developed, drawing on social practice theories of literacy.

\section{The Development of Social Practice Theories of Numeracy}

The idea of literacy as a social practice was first developed in the 1980s by researchers such as Scribner and Cole (1981), Heath (1983), and Street (1984), who studied literacy-in-use in a variety of communities, and such ideas were subsequently applied to numeracy. Rather than regarding numeracy as a set of "stand-alone" mathematical skills, this model views it as a social practice,

A social practice perspective recognizes numeracy as embedded in people's lives at home, work, school or in the community. Numeracy is not regarded as a set of "stand-alone" or autonomous skills to be learned in school and transferred without problems to other domains, but as an ideological practice, embedded in people's purposes as they interact with the social world. For example, students doing calculations while shopping have different purposes and constraints than when they are doing the same calculation in the mathematics classroom.

Street et al. $(2005,20)$ define numeracy practices as "the conceptualisations, the discourse, the values and beliefs, and the social relations that surround numeracy events as well as the contexts in which they are located." Numeracy is seen to be practiced differently in different domains, only one of which is the domain of formal schooling, but Street et al. (2005, 33) draw attention to the distinction between sites - the physical locations in which activities take place and domains as "areas of activity not located in specific places." For example, a student doing mathematics homework is a form of numeracy in which practices from the classroom domain are carried out in the site of the student's home.

It is important to recognize, however, that this model goes beyond "situated numeracy" or "functional numeracy." A social practice perspective not only takes into account different practical contexts; it also considers how people's lifehistories, goals, values and attitudes will influence the way they carry out numeracy.

For example, a group of adult numeracy students who were interviewed after a lesson on ratio was asked whether they would use exact ratios when mixing soft drinks for their families. Some of the students' answers were indeed practical, for example, indicating they would use familiar containers for measurement. The students, however, also spoke about their concerns regarding calories and their children's health, about budgeting for family grocery shopping, and about their pride in their younger children's independence in mixing drinks for themselves (Oughton 2013).

Baker (1998) and Street et al. (2005) argue that a social practice model of numeracy should also take into account cultural and ideological considerations. For example, a social practice perspective acknowledges that certain domains of 
numeracy and mathematics are more highly valued by dominant discourses than others. Many adults tend to dismiss their own practical numeracy skills as "common-sense" and low-status, whereas classroom mathematics is seen as a high-status signifier of intelligence and a gateway (often closed) to many career paths or further study (Coben et al. 2003). Thus the relationship between numeracy and power is acknowledged, and privileging of certain forms of numeracy (such as academic mathematics) over others can be challenged (Baker 1998; Johnston and Yasukawa 2001; Street et al. 2005).

Attempts to apply social practice theories to numeracy have not gone unquestioned. Coben (2006) argues against the implication that adults' numeracy practices are so rich that no further teaching or learning is necessary and also warns that numeracy risks becoming subsumed within "literacies." Green and Howard (2007) suggest that the autonomous "skills model" should be seen as complementary to the "social practice model" and that both have value in developing adult numeracy education.

\section{Functional Numeracy and Learning Transfer}

As stated above, a social practice view of numeracy takes into account the different domains in which numeracy is undertaken, such as college, work, and home. This characterization may at first appear to indicate a "functional" approach to adult numeracy education. A more nuanced understanding of the social practice model, however, reveals a more complex picture. Social practice perspectives take into account people's beliefs, values and goals, and their perception of numeracy as high status, in addition to functionality. The assumption that functional numeracy is the main goal for adult learners is challenged by Swain (2005), who found that few adult learners study mathematics in order to apply it to everyday life, but rather for personal fulfilment. The main reasons were found to include (Swain 2005, 305):

to prove to themselves that they have the ability to study and succeed in a high-status subject, which they perceive to be a signifier of intelligence. The other main reasons are for learners to help their children, and for understanding, engagement and enjoyment.

A gateway qualification such as a GED may also be more important to learners than functional numeracy. Oughton (2014) found that adult numeracy learners were so focussed on passing an essential examination that they did not engage with everyday applications even when encouraged to do so by the teacher. Instead, they concentrated their efforts on working out what they supposed to be the "right" answer.

Coben et al. (2003, 17) suggest that the word "functional" itself is insufficiently examined: 
There are many senses in which numeracy may be considered to be functional: the question is, functional with respect to what context and purpose, for whom and from whose perspective?

Even where "functional numeracy" is agreed to be relevant to the students' purposes and goals, issues of transfer from the classroom to the workplace or other sites of use are found to be highly problematic (Lave 1988; Evans 2000; Fitzsimons 2005). Dowling $(2001,20)$ describes how attempts to set classroom mathematics problems in supposedly real-life contexts merely "mythologise" the practices they are supposed to represent, while Evans and Tsatsaroni $(2000,56)$ warn of the dangers of "an overly simplified notion of context as a 'thin veneer' of applicability, that only seemed to make 'word problems' in the classroom different from abstract calculations" (original emphasis):

The calculations have to be more accurate in the classroom, because that is what is required, or what it takes to keep the teacher happy, and because this is what is a valid answer in school assessment practices (Evans and Tsatsaroni 2000, 59)

In the classroom, students focus on arithmetic skills and the "correct" answer expected by examiners. By contrast, in the workplace, calculators and spreadsheets may reduce the need for basic arithmetic, but employees might need to consider issues of cost-effectiveness, efficiency or safety in their calculations.

Experience and convenient shortcuts replace textbook methods, as in this example of the numeracy used by council employees responsible for minor civil works (Black 2004, 12):

Numeracy skills appeared more significant, such as calculating concrete pours, but these were soon learnt on the job: you've only got to multiply the width by the length ... give us three by four is twelve, that's 1.2 (cubic metres), that's four inches (100 mm in depth) ... you learn that (supervisor). This was not the sort of academic maths learned at school involving the understanding of underlying concepts. Instead, it was an example of performance-driven numeracy; that is, numeracy learned in practice.

In conclusion, then, a social practice model does not necessarily focus on functional numeracy practices. Rather, the model acknowledges and embraces learners' goals, purposes, beliefs and attitudes - whether they be:

- to enjoy the exploration of mathematical patterns and processes for their own sake,

- to cover the curriculum skills needed in order to gain a qualification required for work or further study, or

- to develop situated numeracy practices relevant to their own lives or work.

The essential point is that within a social practice model the distinctions between these different forms of numeracy are made explicit; and the ideologies that value one form of numeracy (such as academic mathematics) over another are challenged and open to critique. 


\section{Revisiting Dominant Discourses with a Social Practice Lens}

Social practice theory thus enables us to revisit and challenge deficit discourses. In particular, it allows us to question whether the assessment methods used by surveys such as PIACC are actually representative of adults' numeracy skills in everyday life and work.

It is interesting to note the definition of numeracy used by the OECD for the PIAAC survey:

the ability to access, use, interpret and communicate mathematical information and ideas in order to engage in and manage the mathematical demands of a range of situations in adult life. To this end, numeracy involves managing a situation or solving a problem in a real context, by responding to mathematical content and concepts represented in multiple ways (OECD 2013a, 4).

This statement at first sounds promising, compatible with a social practice conception of numeracy. However, it is important to question what is meant by a "real" context, and whether such skills and practices can actually be assessed by a survey such as PIAAC.

It is impracticable for major international surveys to use the ethnographic methods needed to find out how adults actually use numeracy in their lives. As with most forms of large-scale mathematical testing, PIAAC assesses numeracy skills via test items; in the case of PIACC, these test items are presented one-at-atime on computer screens. Thus the supposedly "real" contexts, such as commercial or workplace settings, are provided by words and graphics (similar to the "word problems" used in math textbooks and test papers). These test items therefore can be no more than proxy measures of real-life numeracy. The way an individual might solve numerical problems in a genuinely real context - that is, in their own workplace and other everyday practices - is not assessed. How well do these proxy measures reflect adults' real numeracy competencies in their work and everyday lives?

Social practice research and theory suggest that adults' situated numeracy practices are fundamentally different from their approaches to solving test items. In real life, problems are generated by those who solve them, and the problems are structured in terms of social purposes or goals to be achieved. Adults who struggle with classroom mathematics are often found to perform much more competently within meaningful contexts.

Recall how adults were much more likely to be correct in their "best-buy" problem solving in supermarket situations than in attempting the same type of problem as a test item (Capon and Kuhn 1979; Lave 1988). Such findings suggest that test items may underestimate adults' real-world skills, because adults do not 
respond to them as they would in everyday situations. Hamilton and Barton (2000, 384) argue that if:

a bus timetable is wrenched out of its real life context, it ceases to be a timetable and it becomes a test item... we suggest that what these tests are really measuring is an artificially-constructed test-literacy.

An illuminating finding emerges from an additional strand of the PIAAC survey conducted only in the United States. Participants were asked to report what they perceived to be their own level of skills. Many of the participants described themselves as having a higher level of skill than what was indicated by their assessment result. The OECD $(2013 \mathrm{~b}, 26)$ documentation concludes (somewhat disparagingly) that:

many of those with the weakest basic skills do not recognize that they have a problem and/or are unwilling to seek help.

However, social practice theory offers an alternative interpretation - that the participants might be competent in situational skills, which they find sufficient for the everyday contexts in which they use them. According to Hamilton (2016: 3), the media and policy surrounding adult basic education often carry this message, which:

encourages people to imagine themselves as being in a deficit state and in need of help even though they do not necessarily share this vision.

\section{Social Practice Theory and Adult Numeracy Education}

So what might a social practice lens tell us about ways forward for adult numeracy education? Potentially, there is good news and bad news.

Firstly, and encouragingly, social practice theory suggests that many adults' situated numeracy skills may not be as poor as surveys such as PIAAC suggest. As reviewed above, there is a sizeable corpus of research which suggests that adults perform better in real-life numeracy situations that are relevant and meaningful, than they do in word problems with artificial contexts.

Conversely, however, the research also suggests that the transfer of mathematics learned in the classroom to real-life situations is highly problematic - and that attempts to make classroom learning more relevant may disengage students who see it not as "real math."

These conclusions suggest a number of potential areas to address. The first is the (ongoing) attempt to find assessment methods that more realistically assess adults' situated numeracy skills. Grawe (2011), for example, evaluates the strengths and limitations of various approaches to assessment, and concludes the "habits of mind" are an important component of quantitative literacy. Boersma 
and Klyve (2013) tested and evaluated an instrument for "promptless" (or openquestion) assessment that is intended to assess such habits of mind. However, such assessments would be difficult to administer and compare on an international scale. Perhaps a more realistic expectation might be that these alternative forms of assessments would allow us to re-evaluate, and thus calibrate, the results of more conventional large-scale approaches to assessment.

Another possibility is that adult numeracy education policy might reflect a social practice perspective. This idea was attempted in the last decade in Scotland, with mixed results. Adult education policy was directed towards "learnercentered" teaching, with contexts that were relevant to learners. However, while Gardner et al. $(2010,1)$ describe this policy development as "far from perfect but full of promise," Ackland (2006, 39) expresses deeper reservations, suggesting that the critical and ideological dimensions of a social practice model had been neglected, and that a "managerialist discourse is dominating and recontextualizing the more radical discourse of social practices."

However, perhaps the most pragmatic place to start is at "grass-roots" in the adult mathematics classroom - with the attitudes and approaches taken by adult educators.

One example of this strategy is the funds of knowledge approach to adult learning. This approach shares many of the same principles and intentions as social practice theory; specifically, it places value on the informal knowledge and experience possessed by adult students, recognizes the situated nature of numeracy practices in different contexts, and challenges the claim that some forms of knowledge (such as academic mathematics) are more legitimate than others (Moll et al. 1992; Gonzalez, Moll and Amanti 2005; Civil 2016).

Moll et al. (1992) carried out ethnographic research among Mexican families in Arizona, and concluded that households had "funds of knowledge" that were relevant and useful in the home but little valued by educational discourse; those "funds" included knowledge and skills associated with agriculture and mining, economics, household management, medicine and religion. Moll et al. $(1992,134)$ suggested that the funds of knowledge identified by their study represent "a positive and realistic view of households as containing ample cultural and cognitive resources with great potential utility for classroom instruction."

Baker (2005), who was also an early proponent of social practice theory (Baker 1998), uses a broader definition of funds of knowledge and applies the concept to adult numeracy classrooms. With the broader definition, which resonates with a social practice perspective on adult numeracy, "funds" include (Baker 2005, 16):

- knowledge, experiences, histories, identities and images of themselves;

- attitudes, dispositions, desires, values, beliefs, and social and cultural relations; 
- relationships with learning, teachers and mathematics itself;

- and numeracy practices beyond the classroom.

While a broadening of the definition does bring its own challenges (Oughton 2010), it is particularly relevant to adult learners. Questioning the deficit model often promoted by policy, recognition of a wider range of knowledge, practices and experiences allows teachers to acknowledge and build on the personal, interpersonal and metacognitive resources of mature adults.

Baker (2005) and Baker and Rhodes (2007) examine the "broader" funds of knowledge brought to adult numeracy classrooms, and they conclude that teachers do not always make use of these in formal classrooms. They point out that dominant approaches to teaching numeracy tend to be about assessing what students cannot do, and suggest that, instead, teachers could work with what students can do as a starting point for gaining the skills and knowledge required in formal numeracy classrooms. Teachers participating in a funds-of-knowledge approach during the project felt that through their engagement with the concept they had become more critically self-reflective about their teaching.

Of particular relevance in a U.S. context is Marta Civil's work, also in the U.S.-Mexican borderlands in Arizona, with parents as adult learners of mathematics (Civil 2006, 2016). For example, Civil, as teacher, took on the role of learner to experience the mathematics embedded in dressmaking (Civil 2016, 54):

In my analysis of a seamstress' practice, I noted that to make the pattern for a skirt she made a quarter of a circle in such a way that it showed the circle as the locus of all points equidistant from a central point. Yet, this seamstress did not have a course in formal geometry, nor did she talk about the circle in these terms.

She earlier had found that the participating adults did not value their own informal numeracy methods; they asked to be shown the "proper way" (Civil 2006, 2). Regarding the experience with the seamstress (Civil 2016, 53):

As we discussed the activity of sewing with a group of teachers, one of them, who was an experienced seamstress said, 'you do not have to do math; you just measure.' This teacher would often mention that as a student, she found the subject of mathematics to be hard. Sewing, on the other hand, was easy to her. It is interesting to note that she did not seem to see mathematics and sewing as having any connections and that 'measuring' did not seem to be part of doing mathematics for her.

In her conclusion, Civil lists numerous points about effective approaches for adult learning, and she notes the resonances with Lave and Wenger's learning as participation model ( Lave and Wenger 1991; Sfard 1998):

- They learned through observation, by replicating samples, and by taking them apart when possible.

- They learned by participation in the practice, through interaction with others. 
- They took great pride in their work and showed a passion for what they did.

- They indicated desire and persistence as characteristics to becoming good at their practice.

- They mentioned imagination (picturing the product) and communication (with their customers) as factors in their learning of the practice.

- They noted the need to feel challenged as being important in their learning process.

A funds of knowledge approach is clearly not without its own tensions and contradictions. As noted above, students have also been found not to value their own informal methods (Civil 2016), while Oughton (2014) observed that students were more focussed on preparing for qualifications than drawing on their own funds of knowledge. Concerns have also been expressed about the economic metaphor, suggesting that it is more reminiscent of human capital (or 'banking') models of education (Oughton 2010; Hinton 2015).

Looking back on nearly three decades of the funds of knowledge approach, Civil $(2016,53)$ reflects that it is still not considered "mainstream" research:

While these accounts are important, particularly in that they can help redefine what counts as mathematics, who does mathematics, and where mathematics is located, I still think that often these accounts are kept separate from the "mainstream" research. For example, did any of the research that looks at mathematics from a cultural point of view influence the development of the Common Core State Standards for Mathematics. Should it?

Knijnik (1993, 25) argues that "merely glorifying popular knowledge does not contribute to the process of social change," a claim adopted and applied to adult numeracy by Civil (2003, 3):

There are different forms of mathematics, each associated with a different discourse and set of values. Our task, I think, is to accept and value these different forms and bring them into the open for discussion.

\section{Conclusion}

I have argued that dominant discourses tend to prioritize the importance of economic effectiveness, global competition, and the development of adult skills to enhance success in those arenas. The numeracy promoted as necessary for adults to learn falls within a "limited proficiency" model: the functional arithmetical competences that are perceived to be useful for the workplace and in which many adults are seen to be "in deficit." This viewpoint has become so naturalized that it has been accepted and internalized by both teachers and adult students, who have become complicit in its implementation throughout adult basic education. As Yasukawa and Black $(2016, \mathrm{x})$ claim: 
an economistic discourse has increasingly taken centre stage influencing: how literacy and numeracy are conceptualised, the rationale for programs, the ways learners are talked about, and how the professional identities of practitioners are formed.

My aim in this article has been to show how a social practice model offers a critical lens through which dominant discourses can be questioned and challenged, and alternative approaches sought. This lens does not necessarily focus on "functional" numeracy for global competitiveness, but acknowledges and embraces adults' situated numeracy practices, together with their beliefs, attitudes and personal goals. These goals may indeed be to learn the skills needed for the workplace. However, they may also be to gain a GED; to achieve quantitative literacy for critical citizenship; or even to study pure mathematics simply for the joy of it.

\section{References}

Ackland, A. 2006. "Lizard Dressed as Lamb? A Cautionary Reading of the Discourse of the Scottish Adult Literacies Initiative. Research and Practice in Adult Literacy: RaPaL Journal 60: 37-45.

American Institutes for Research (AIR). 2014. What the Data Say about the Skills of U.S. Adults. http://static.squarespace.com/static/51bb74b8e4b0139570ddf020/t/535fdfdbe 4b032825e56cbf8/1398792155103/PIAAC\%20Results\%20Summary\%20Bro chure_Final_041814.pdf (accessed August 31 2017)

Baker, D. 1998. "Numeracy as Social Practice; An Adult Education Context in South Africa. Journal of Literacy and Numeracy Studies 8 (1): 37-50.

- 2005. "Numeracy and 'Funds of Knowledge." Reflect 3: 16-17.

- , and V. Rhodes. 2007. Making Use of Learners Funds of Knowledge for Mathematics and Numeracy: Improving Teaching and Learning of Mathematics and Numeracy in Adult Education NCETM / Maths4Life.

Barton, D., and M. Hamilton. 1998. Local Literacies: Reading and Writing in One Community. London: Routledge. https://doi.org/10.4324/9780203448885

Boersma, S. and D. Klyve. 2013. "Measuring Habits of Mind: Toward a Promptless Instrument for Assessing Quantitative Literacy." Numeracy 6 (1): Art. 6. https://doi.org/10.5038/1936-4660.6.1.6

Capon, N. and D. Kuhn, D. 1979. "Logical Reasoning in the Supermarket: Adult Females' Use of a Proportional Reasoning Strategy in an Everyday Context." Developmental Psychology 15 (4): 450-452.

Carraher, T., D. Carraher, and A. Schliemann. 1985. "Mathematics in the Streets and in Schools." British Journal of Developmental Psychology 3: 21-29.

Civil, M. 2003. "Adult Learners of Mathematics: A Look at Issues of Class and Culture. Keynote address." In Policies and Practices for Adults Learning 
Mathematics: Opportunities and risks, ed. J. Evans, P. Healy, D. Kaye, V. Seabright and A. Tomlin, 13-23. Proceedings of the $9^{\text {th }}$ International Conference of Adults Learning Mathematics (ALM9). London: ALM. . 2006. "Building on Community Knowledge: An Avenue to Equity in Mathematics Education." In Improving Access to Mathematics: Diversity and Equity in the Classroom, ed. N. Nasir and P. Cobb. New York: Teachers College Press.

- 2016. "STEM Learning Research Through a Funds of Knowledge Lens. Cultural Studies of Science Education 11 (1): 41-59.

Coben, D. 2001. "Fact, Fiction and Moral Panic: The Changing Adult Numeracy Curriculum in England." In Adult and Life-long Education in Mathematics, ed. J. O'Donoghue \& D. Coben, 125-153. Papers from Working Group for Action 6, 9th International Congress on Mathematical Education. Melbourne: Language Australia in association with ALM.

- 2006. "The Social-Cultural Approach to Adult Numeracy: Issues for Policy and Practice." In Adult Literacy, Numeracy and Language: Policy, Practice and Research, ed. L. Tett, M. Hamilton and Y. Hillier, 96-107 Maidenhead: Open University Press.

$\longrightarrow$, D. Colwell, S. Macrae, J. Boaler, M. Brown, and V. Rhodes. 2003. Adult Numeracy: Review of Research and Related Literature. London: NRDC.

Cook, G. 1989. Discourse. Oxford: Oxford University Press.

Crystal, D. 1992. Introducing Linguistics. Harmondsworth: Penguin.

Dowling, P. 2001. "Mathematics Education in Late Modernity: Beyond Myths and Fragmentation." In Sociocultural Research on Mathematics Education: An International Perspective, ed. B. Atweh, H. Forgasz and B. Nebres, 19-36. Mahwah NJ: Lawrence Erlbaum Associates.

Evans, J. 2000. Adults Mathematical Thinking and Emotions: A Study of Numerate Practices. London: Routledge Falmer.

- 2014. "New PIAAC Results: Care Is Needed in Reading Reports of International Surveys." Adults Learning Mathematics: An International Journal, 9 (1): 37-52.

—, and A. Tsatsaroni. 2000. "Mathematics and its Publics: Texts, Contexts and Users." Social Epistemology 14 (1): 55-68.

Fairclough, N. 1989. Language and Power. London: Longman.

FitzSimons, G. 2005. "Can Adult Numeracy Be Taught? A Bernsteinian Analysis." Mathematics Education and Society Conference 2005.

Gardner, A., M. Hamilton, C. Pinsent-Johnson, R. Darville, and T. Atkinson. 2010. "Tensions between Policy, Practice and Theory: International Perspectives on Adult Literacy." Conference Proceedings, Canadian Association for the Study of Adult Education (CASAE): 349-353. 
Gee, J. 1996. Social Linguistics and Literacies: Ideology in Discourses $\left(2^{\text {nd }}\right.$ Edition). London: Falmer.

Gonzalez, N., L. Moll, and C. Amanti. 2005. Funds of Knowledge: Theorizing Practices in Households, Communities, and Classrooms, New York: Laurence Erlbaum.

Grawe, N. 2011. "Beyond Math Skills: Measuring Quantitative Reasoning in Context." New Directions for Institutional Research 2011 (149): 41-52.

Green, A. and U. Howard. 2007. Skills and Social Practices: Making a Common Cause. London: NRDC

Hamilton, M. 2016. “Imagining Literacy.” In Beyond Economic Interests, ed. K. Yasukawa and S. Black, 3-17. Rotterdam: SensePublishers. https://doi.org/10.1007/978-94-6300-444-2_1

and D. Barton. 2000. "The International Adult Literacy Survey: What Does It Really Measure?" International Review of Education 46 (5): 377389. https://doi.org/10.1023/A:1004125413660

Heath S. B. 1983. Ways with Words: Language, Life, and Work in Communities and Classrooms. Cambridge: Cambridge University Press.

Hinton, K. 2015. "Should We Use a Capital Framework to Understand Culture? Applying Cultural Capital to Communities of Color. Equity \& Excellence in Education 48 (2): 299-319.

Johnston, B. and K. Yasukawa. 2001.” Numeracy: Negotiating the World through Mathematics." In Sociocultural Research on Mathematics Education: An International Perspective, ed. B. Atweh, H. Forgasz and B. Nebres, 279-294. Mahwah NJ: Lawrence Erlbaum Associates.

Karaali, G., E. H. Villafane Hernandez, and J. A. Taylor. 2016. "What's in a Name? A Critical Review of Definitions of Quantitative Literacy, Numeracy, and Quantitative Reasoning." Numeracy 9 (1): Art. 2.

Knijnik, G. 1993. “An Ethnomathematical Approach in Mathematical Education: A Matter of Political Power." For the Learning of Mathematics 13 (2): 23-25.

Lave, J. 1988. Cognition in Practice. Cambridge: Cambridge University Press.

— Participation. Cambridge: Cambridge University Press. https://doi.org/10.1017/CBO9780511609268

Lerman, S. 2000. "The Social Turn in Mathematics Education Research. In International Perspectives on Mathematics Education, ed. J. Boaler, 19-44. Westport CT: Ablex, 19-44.

Luke, A 1995. "Text and Discourse in Education: An Introduction to Critical Discourse Analysis." Review of Research in Education, 21: 3-48. 
Moll, L., C. Amanti, D. Neff, and N. González, N. 1992. "Funds of knowledge for Teaching: Using a Qualitative Approach to Connect Homes and Classrooms." Theory into Practice 31: 132-141.

NCES 2016. Skills of U.S. Unemployed, Young, and Older Adults in Sharper Focus. Washington: National Center for Education Statistics, Institute of Education Sciences.

Nunes, T., A. Schliemann, and D. Carraher. 1993. Street Mathematics and School Mathematics. Cambridge: Cambridge University Press.

OECD. 2013a. Skilled for Life? Key Findings from the Survey of Adult Skills. Organisation for Economic Co-operation and Development. Available at www.oecd.org/skills/piaac/SkillsOutlook_2013_ebook.pdf (accessed August 31 2017).

- 2013b. Time for the U.S. to Reskill? What the Survey of Adult Skills Says. Paris: OECD Publishing. https://doi.org/10.1787/9789264204904-en (accessed August 31 2017).

Oughton, H. 2007. "Constructing the 'Ideal Learner': A Critical Discourse Analysis of the Adult Numeracy Core Curriculum." Research in PostCompulsory Education 12 (2): 259-275.

- 2010. "Funds of Knowledge: A Conceptual Critique." Studies in the Education of Adults 42 (1): 63-78.

- 2013. "The Social Context of Adult Numeracy." In Teaching Adult Numeracy: Principles and Practice, ed. G. Griffiths and R. Stone., Maidenhead: Open University Press.

—. 2014. “'I Think We've Done It Right.' The Curriculum and Performative Discourse in Adult Basic Education Classrooms." In Student Experiences and Perspectives of Performativity from International Contexts and Ethnographic Research, ed. B. Jeffrey, A. Rasmussen and J. Gustafsson. Stroud: E\&E Publishing http://ubir.bolton.ac.uk/1007/ (accessed August 31, 2017).

Papen, U. 2005. Adult Literacy as Social Practice: More than Skills (New Approaches to Adult Language, Literacy and Numeracy). Oxford: Routledge. https://doi.org/10.4324/9780203347119

Saxe, G. 1988. "Candy Selling and Math Learning." Educational Researcher 17 (6): 14-21.

Scribner, S., and Cole, M. 1981. The Psychology of Literacy: A Case Study among the Vai. Boston: Harvard University Press. https://doi.org/10.4159/harvard.9780674433014

Sfard, A. 1998. "On Two Metaphors for Learning and the Dangers of Choosing Just One." Educational Researcher 27 (2): 4-13.

Street, B. 1984. Literacy in Theory and Practice. Cambridge: Cambridge University Press. 
- D. Baker, and A. Tomlin. 2005. Navigating Numeracies: Home/School Numeracy Practices. Dordrecht: Kluwer.

Swain, J. 2005. “'Beyond the Daily Application': Motivations for Adults Attending Numeracy Classes." Research in Post-Compulsory Education 10 (3): 305-323.

Tunstall, S. L. 2016. "Words Matter: Discourse and Numeracy." Numeracy 9 (2): Art. 5. https://doi.org/10.5038/1936-4660.9.2.5

Wodak, R. and M. Meyer, M. 2015. Methods of Critical Discourse Studies. London: Sage.

Yasukawa, K. and S. Black, S. (Eds). 2016. Beyond Economic Interests: Critical Perspectives on Adult Literacy and Numeracy in a Globalised World. Rotterdam: Sense Publishers. 